\title{
EFFECTS OF EXPERIMENTALLY INDUCED COLIBACILLOSIS ON THE PHARMACOKINETICS OF OFLOXACIN IN CHICKENS
}

\author{
El-Seedi, I.A. \\ Biochemistry Dept., Animal Health Research Institute, Dokki
}

\begin{abstract}
Colibacillosis was produced experimentally in 14 white Leghorn broiler chickens by intratracheal inoculation of $0.3 \mathrm{ml}$ broth of $E$. coli O78:K80 containing approximately $10^{6}$ colony forming unit. Another 7 clinically normal chickens were used in this study. Ofloxacin was administered to chickens intravenously and orally (5 $\mathrm{mg} / \mathrm{kg} \mathrm{b.wt}$.) to determine the effect of colibacillosis on its kinetic behavior.

The concentration of ofloxacin in serum samples collected at prescheduled time were estimated by using microbiological assay. The pharmacokinetic parameters were determined by two compartment open model. The drug concentration $(\geq 0.1 \mu \mathrm{g} / \mathrm{ml})$ was maintained up to 24 $h$. There were statistically $(P<0.05)$ significant differences between normal and colibacillosed chickens represented by half-time of elimination,transfer rate constants, elimination rate constant,apparent volume of the central compartment and body clearance of the drug following intravenous administration. Following oral administration the absorp-tion rate constant, absorption half-life and the time needed to reach the maximum concentration were statistically $(P<0.05)$ significantly diffe-rent between normal and colibacillosed chickens.

The bioavailability of ofloxacin in normal chickens following oral administration was found to be $91.9 \pm 8.25 \%$. The in vitro protein binding of ofloxacin in normal chicken serum at different concentrations was $15.98 \pm 0.92 \%$. Based on these kinetic parameters clinical application of ofloxacin at a dose of $5 \mathrm{mg} / \mathrm{kg}$ at $24 \mathrm{~h}$ dosing interval by intravenous or oral administration in chickens is recommended.
\end{abstract}




\section{INTRODUCTION}

Colibacillosis is a wide disease of poultry, caused by a small number of pathogenic strain of $E$. coli and resulting in heavy economic losses (Barnes and Gross, 1997). The disease is characterized in its acute form by septicemia resulting in death and in its subacute form by pericarditis, airsaculitis and perihepatitis (Cheville and Arp, 1978).

Except for the extensive work on the relationship of renal and hepatic disease on drug elimination and therapy, experimental studies on the effects of disease on drug disposition are few (Wellington and Craig, 1976). Marked alterations in drug disposition under disease conditions where tissue permeability, $\mathrm{pH}$ and other factors may be significantly altered may have profound implications regarding both efficacy and toxicity.

Ofloxacin is one of a new generation of fluorinated quinolones structurally related to nalidixic acid. It is a broad spectrum antibacterial drug active against most Gram- negative bacteria, many Gram- positive bacteria and some anaerobes (Monk and Campoli, 1987). Ofloxacin has been introduced into human medicine and because of its breadth and intense activity against Gram- negative bacteria, Mycoplasma spp., Chlamydia spp and Rickettsia spp., it was proposed for veterinary medicine use (Lamp et al., 1992).

Ofloxacin as more completely absorbed achieves, high peak serum concentrations and has long terminal elimination half- life which results in a great area under the curve when administered orally (Wolfson and Hooper, 1989 and Son et al., 2000).

The pharmacokinetic properties of ofloxacin have not been extensively studied in different animal species. However there are several single reports in rabbits (Perkins et al., 1995), chicken (Liu and fung, 1997), goats (Barum et al., 2000) and in dogs (Yabe et al., 2001). 
Therefore the purpose of this study was to investigate the pharmacokinetic behaviour of ofloxacin in healthy chickens and chickens infected with $E$. coli after a single intravenous and oral administration, Systemic bioavailability in healthy chickens after oral administration in normal chicken and in-vitro protein binding of ofloxacin serum also were determined.

\section{MATERIALS AND METHODS}

\section{Drug:}

Ofloxacin pure powder equivalent to $100 \%$ of ofloxacin was kindly supplied from Kahira Pharm.\& Chem. Ind. Co. Egypt. It was used as standard for microbiological assay and chicken administration. Drug was dissolved in $0.1 \mathrm{~N} \mathrm{NaOH}$ to a concentration of $10 \mathrm{mg} / \mathrm{ml}$ and there after titrated with concentrated $\mathrm{HCl}$ to a neutral $\mathrm{pH}$ before administration (Kemmerich et al., 1986).

\section{Escherichia coli:}

Nutrient broth culture of E.coli O78: K80 containing approximately $10^{6}$ colony forming unit/ $\mathrm{ml}$ was obtained from poultry department, microbiology unit, Animal Health Research Institute.

\section{Chickens:}

Healthy adult White Leghorn broiler chickens of $2.10 \pm 0.3 \mathrm{~kg}$ body weight were obtained from commercial source. The chickens were placed in cages in the animal house and fed on a balanced ration free from antibiotic and water were ad libitum two weeks before and through out the experiment.

\section{Experimental design:}

The pharmacokinetic study of ofloxacin was performed in two experiments. 


\section{Experiment-1:}

Seven clinically normal chickens were used in this work. Each chicken was injected $5 \mathrm{mg}$ ofloxacin/ $\mathrm{kg}$ b.wt into the right wing vein, then these chicken left for 15 days to insure complete excretion of ofloxacin from their bodies. After that each chicken was administered orally with $5 \mathrm{mg}$ ofloxacin/ $\mathrm{kg}$ b.wt.

\section{Experiment-2:}

Fourteen chickens were inoculated intratrachealy with $0.3 \mathrm{ml}$ of $E$. coli broth culture. These chickens were subjected to fluctuating air temperature four days before infection as stress factor to enhance $E$. coli infection (Pages and Costa, 1985). Four days after infection the chickens were divided into 2 groups ( 7 chickens/ group). Each chicken in group 1 was injected intravenously into the right wing vein with $5 \mathrm{mg}$ ofloxacin/ $\mathrm{kg}$ b.wt. Meanwhile, each chicken in group 2 was administered orally with $5 \mathrm{mg}$ ofloxacin / $\mathrm{kg}$ b.wt.

Food but not water was withheld for 12 hours before oral dosing until 6 hours after drug administration.

\section{Collection of samples:}

After ofloxacin administration in each study $0.5 \mathrm{ml}$ blood samples were collected from the left wing vein at 10,20 and 30 minutes and at 1, $2,4,8,12$ and 24 hours. Sera prepared from the blood samples were frozen at $-20^{\circ} \mathrm{C}$ until analysis.

\section{Drug assay:}

Serum ofloxacin concentrations were determined by use of an agarwell diffusion biological assay with $E$. coli as the test organism (Arret et al., 1971).

A standard curve of 16 to $0.032 \mu \mathrm{g}$ of ofloxacin/ $\mathrm{ml}$ of chicken serum and solvent solution were used to calculate ofloxacin serum concentrations in the treated chickens and serum protein binding. Ofloxacin protein 
binding was determined based in the fact that only free unbound part of antibiotic is capable to diffuse through agar. The equation described by Lorian (1975) was used to calculate the percent age of protein binding of the tested antibiotic from the difference in the diameter of inhibition zones in solvent solution $(\mathrm{pH}, 7)$ and those in serum at different concentrations of antibiotic.

\section{Pharmacokinetic analysis:}

The pharmacokinetic parameters were calculated from concentration vs. Time curves according to Baggot $(1977,1978)$ and Gibaldi and Perier (1982).

The obtained data were statistically analysed as mean \pm standard error ( $\mathrm{M} \pm$ S.E) according to Berly and Lindgren (1990).

\section{RESULTS}

The response to induction of $E$. coli with Lasota strain in chickens produce moderate depression, anorexia, ruffled feathers and diarhhoea 48 hrs post-inoculation and lasted for about 4 days.

The change of drug concentrations in serum after ofloxacin intravenous or oral administration was considered with a two-compartment open model pharmacokinetic analysis.

The pharmacokinetic parameters for normal and E. coli infected chickens following single intravenous or oral administration of $5 \mathrm{mg}$ ofloxacin/kg b.wt. are shown in tables 1 and 2 as well as illustrated in Fig. 1 and 2, respectively.

Following a single intravenous injection of $5 \mathrm{mg}$ ofloxacin $/ \mathrm{kg}$ b.wt. in normal and $E$. coli infected chickens, the comparison of serum drug concentration at 0 time $\left(\mathrm{C}^{0}\right)$, intercept of distribution phase $(\mathrm{A})$, half-time of elimination $\left(\mathrm{t}_{0.5(\beta)}\right)$, transfer rate constant $\left(\mathrm{K}_{12} \& \mathrm{~K}_{21}\right)$, elimination rate constant $\left(\mathrm{K}_{10}\right)$, apparent volume of the central compartment $\left(\mathrm{V}^{1} \mathrm{c}\right)$ and body clearance of drug $\left(\mathrm{CL}_{\mathrm{B}}\right)$ revealed statistically significantly different. 
Following a single oral administration, the absorption rate constant $\left(\mathrm{K}_{\mathrm{ab}}\right)$, absorption half life $\left(\mathrm{t}_{0.5(\mathrm{ab})}\right)$ and the time needed to reach the maximum concentration $\left(\mathrm{t}_{\max }\right)$ are statistically significant difference between normal and E.coli infected chickens. The area under the serum drug concentrationtime curve (AUC) following oral and intravenous administration in the same normal chickens revealed systemic bioavailability percent equal to $91.9 \pm 8.25 \%$ (Fig.,3). The in-vitro protein binding of ofloxacin in normal chicken serum at different concentrations was $15.98 \pm 0.92 \%$ as shown in table 3.

Table (1): Pharmacokinetic determinants of ofloxacin in normal and E. coli infected chickens following a single intravenous dose of $5 \mathrm{mg} / \mathrm{kg}$ b.wt $(n=7)$.

\begin{tabular}{|c|c|c|c|}
\hline Parameters & Units & Normal chickens & $\begin{array}{l}\text { E. coli infected } \\
\text { chickens }\end{array}$ \\
\hline $\mathrm{C}_{0}$ & $\mu \mathrm{g} / \mathrm{ml}$ & $18.74 \pm 1.55$ & $10.76 \pm 0.83^{*}$ \\
\hline A & $\mu \mathrm{g} / \mathrm{ml}$ & $17.95 \pm 1.72$ & $9.93 \pm 0.67 *$ \\
\hline$\alpha$ & $\mathrm{h}^{-1}$ & $4.02 \pm 0.37$ & $3.29 \pm 0.22$ \\
\hline $\mathrm{t}_{0.5(\alpha)}$ & $\mathrm{h}$ & $0.17 \pm 0.02$ & $0.21 \pm 0.02$ \\
\hline $\mathrm{B}$ & $\mu \mathrm{g} / \mathrm{ml}$ & $0.79 \pm 0.05$ & $0.83 \pm 0.06$ \\
\hline$\beta$ & $\mathrm{h}^{-1}$ & $0.08 \pm 0.007$ & $0.10 \pm 0.01$ \\
\hline $\mathrm{t}_{0.5(\beta)}$ & $\mathrm{h}$ & $8.66 \pm 0.51$ & $6.93 \pm 0.41^{*}$ \\
\hline $\mathrm{K}_{12}$ & $\mathrm{~h}^{-1}$ & $2.60 \pm 0.19$ & $2.11 \pm 0.17 *$ \\
\hline $\mathrm{K}_{21}$ & $\mathrm{~h}^{-1}$ & $0.24 \pm 0.02$ & $0.34 \pm 0.02 *$ \\
\hline $\mathrm{K}_{10}$ & $\mathrm{~h}^{-1}$ & $1.26 \pm 0.09$ & $0.93 \pm 0.07 *$ \\
\hline $\mathrm{K}_{12} / \mathrm{K}_{21}$ & - & $10.83 \pm 1.15$ & $6.21 \pm 0.73^{*}$ \\
\hline $\mathrm{VC}^{1}$ & $\mathrm{~L} / \mathrm{kg}$ & $0.27 \pm 0.02$ & $0.46 \pm 0.03^{*}$ \\
\hline $\mathrm{Vd}_{(\beta)}$ & $\mathrm{L} / \mathrm{kg}$ & $4.50 \pm 0.37$ & $4.40 \pm 0.41$ \\
\hline $\mathrm{Vd}_{(\mathrm{ss})}$ & $\mathrm{L} / \mathrm{kg}$ & $2.07 \pm 0.20$ & $2.47 \pm 0.21$ \\
\hline $\mathrm{Vd}_{\text {(area) }}$ & $\mathrm{L} / \mathrm{kg}$ & $4.50 \pm 0.48$ & $4.42 \pm 0.41$ \\
\hline MRT & $\mathrm{h}$ & $5.75 \pm 0.33$ & $5.61 \pm 0.44$ \\
\hline $\mathrm{Cl}_{\mathrm{B}}$ & $\mathrm{L} / \mathrm{h} / \mathrm{kg}$ & $0.36 \pm 0.02$ & $0.44 \pm 0.03 *$ \\
\hline $\mathrm{AUC}_{0-24}$ & $\mu \mathrm{g} / \mathrm{h} / \mathrm{ml}$ & $13.82 \pm 1.11$ & $11.33 \pm 0.93$ \\
\hline
\end{tabular}

* Significant at $\mathrm{P}<0.05$ 
Table (2): Pharmacokinetic determinant of ofloxacin in normal and E. coli infected chickens after single oral administration of $5 \mathrm{mg} / \mathrm{kg} \mathrm{b.wt}$ $(\mathrm{n}=7)$.

\begin{tabular}{|c|c|c|c|}
\hline Parameters & Units & Normal chickens & $\begin{array}{l}E \text {. coli infected } \\
\text { chickens }\end{array}$ \\
\hline A & $\mu \mathrm{g} / \mathrm{ml}$ & $1.42 \pm 0.12$ & $1.20 \pm 0.13$ \\
\hline $\mathrm{K}_{\mathrm{ab}}$ & $\mathrm{h}^{-1}$ & $1.90 \pm 0.10$ & $2.51 \pm 0.11^{*}$ \\
\hline $\mathrm{t}_{0.5(\mathrm{ab})}$ & $\mathrm{h}$ & $0.36 \pm 0.03$ & $0.28 \pm 0.02 *$ \\
\hline Lag time & $\mathrm{h}$ & $0.16 \pm 0.02$ & $0.16 \pm 0.01$ \\
\hline $\mathrm{B}$ & $\mu \mathrm{g} / \mathrm{ml}$ & $1.42 \pm 0.13$ & $1.20 \pm 0.10$ \\
\hline $\mathrm{K}_{\mathrm{el}}$ & $\mathrm{h}^{-1}$ & $0.10 \pm 0.01$ & $0.11 \pm 0.01$ \\
\hline $\mathrm{T}_{0.5(\beta)}$ & $\mathrm{h}$ & $7.00 \pm 0.55$ & $6.44 \pm 0.43$ \\
\hline $\mathrm{T}_{\max }$ & $\mathrm{h}$ & $1.80 \pm 0.14$ & $1.47 \pm 0.09 *$ \\
\hline $\mathrm{C}_{\max }$ & $\mu \mathrm{g} / \mathrm{ml}$ & $1.14 \pm 0.11$ & $0.99 \pm 0.07$ \\
\hline MRT & $\mathrm{h}$ & $8.05 \pm 0.66$ & $7.65 \pm 0.51$ \\
\hline MAT & $\mathrm{h}$ & $2.30 \pm 0.19$ & $2.04 \pm 0.15$ \\
\hline $\mathrm{AUC}_{0-24}$ & $\mu \mathrm{g} / \mathrm{h} / \mathrm{ml}$ & $12.70 \pm 0.91$ & $10.12 \pm 0.77$ \\
\hline $\mathrm{F}$ & $\%$ & $91.90 \pm 8.25$ & - \\
\hline
\end{tabular}

* Significant at $\mathrm{P}<0.05$

Table (3): In vitro serum protein binding of ofloxacin in normal chicken.

\begin{tabular}{|c||c|c||c|}
\hline \multirow{2}{*}{$\begin{array}{c}\text { Ofloxacin } \\
\text { concentrations } \\
(\mu \mathrm{g} / \mathrm{ml})\end{array}$} & \multicolumn{2}{|c|}{$\begin{array}{c}\text { Average corrected values of } \\
\text { inhibition zones }(\mathrm{mm})\end{array}$} & \multirow{2}{*|}{$\begin{array}{c}\text { Average protein } \\
\text { binding }(\%)\end{array}$} \\
\cline { 2 - 3 } & $\begin{array}{c}\text { Solvent } \\
(\mathrm{pH} 7)\end{array}$ & $\begin{array}{c}\text { Normal chicken } \\
\text { serum }\end{array}$ & \\
\hline \hline 0.25 & 15.25 & 12.61 & 17.31 \\
\hline 0.5 & 16.45 & 13.33 & 18.96 \\
\hline 1.00 & 18.31 & 15.66 & 14.47 \\
\hline 2.00 & 20.10 & 17.21 & 14.38 \\
\hline 4.00 & 22.00 & 18.75 & 14.77 \\
\hline X \pm S.E. & & & $15.95 \pm 0.92$ \\
\hline
\end{tabular}

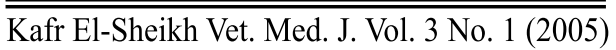


El-Seedi, I.A.

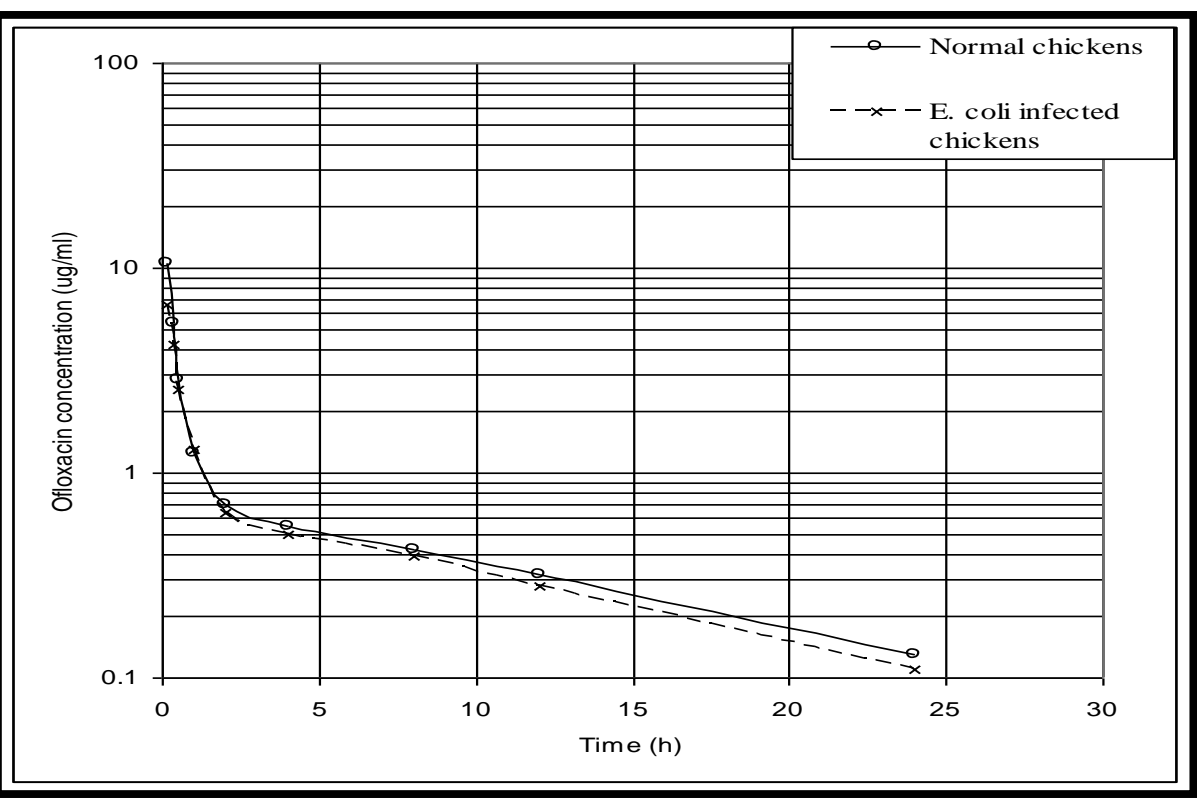

Fig. (1): Comparison of the mean serum concentrations of ofloxacin following intravenous administration of $5 \mathrm{mg} / \mathrm{kg}$ b.wt. in normal and $E$. coli infected chickens.

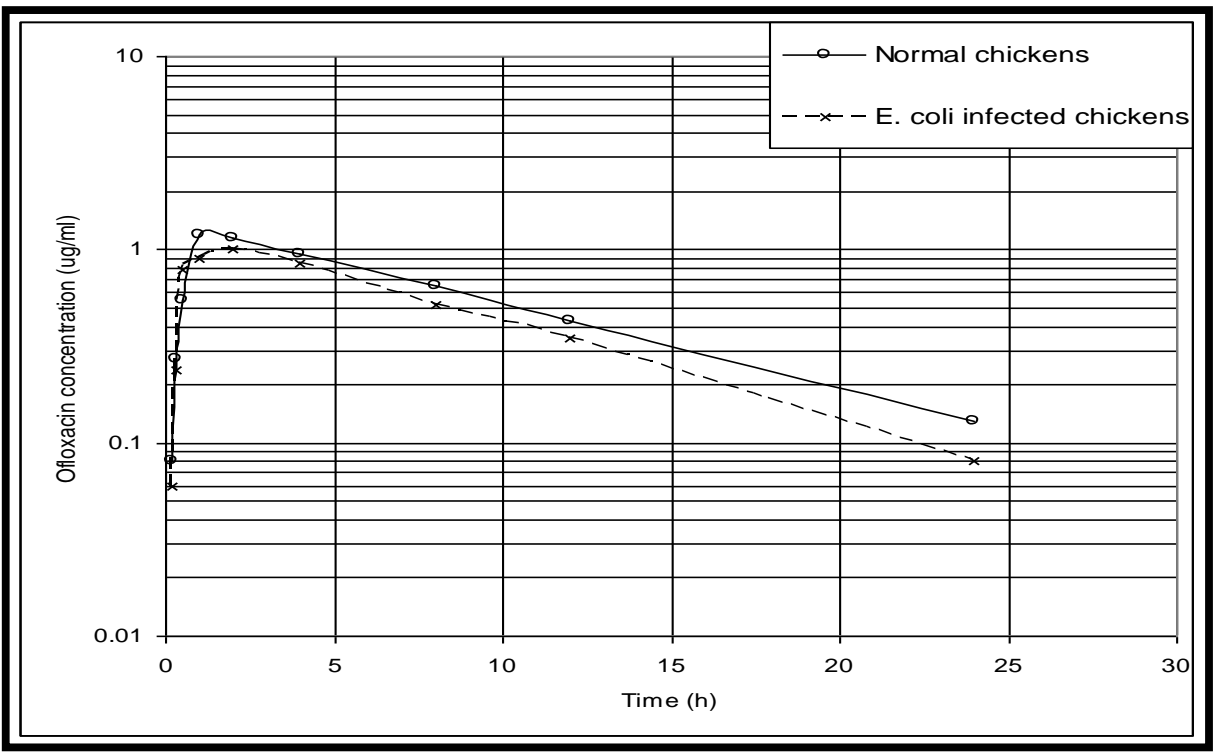

Fig. (2): Comparison of the mean serum concentrations of ofloxacin following oral administration of $5 \mathrm{mg} / \mathrm{kg} \mathrm{b.wt}$. in normal and E. coli infected chickens.

$\overline{\text { Kafr El-Sheikh Vet. Med. J. Vol. } 3 \text { No. } 1 \text { (2005) }}$ 


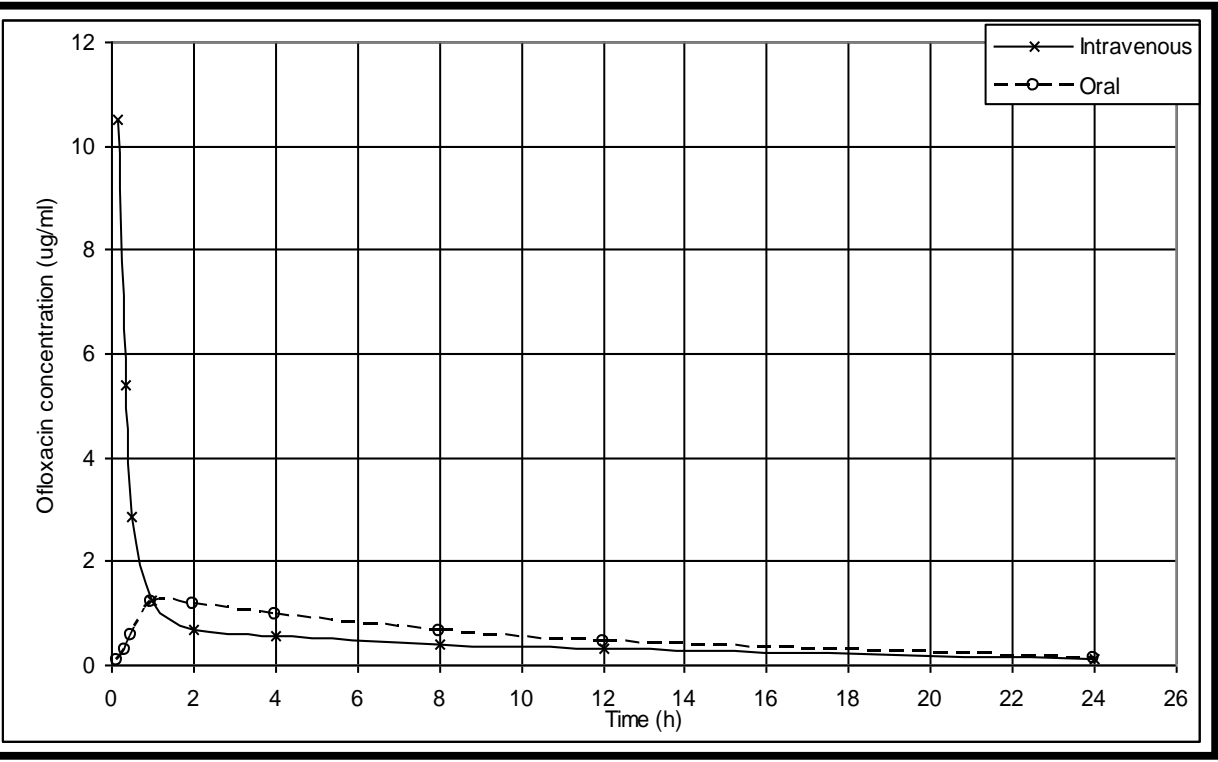

Fig. (3): Arithmetic plot of serum drug concentrations in the same normal chickens following single intravenous and oral administration of $5 \mathrm{mg}$ ofloxacin/ $\mathrm{kg} \mathrm{b.wt}$.

\section{DISCUSSION}

Colibacillosis was produced in each infected chicken as evidenced by the depression, anorexia, ruffled feathers and diarrhea. While, the symptoms were not consistent in severity among the infected chickens, this was not a limiting factor because the purpose of the experiment was to evaluate the effects of a disease on disposition of ofloxacin and not to evaluate the ofloxacin effectiveness.

ollowing a single intravenous administration of $5 \mathrm{mg}$ ofloxacin $/ \mathrm{kg}$ b.wt. in normal and infected chickens. The drug could be detected for 24 hours with mean values of 0.13 and $0.11 \mu \mathrm{g} / \mathrm{ml}$ in normal and diseased chicken, respectively. These values exceeded the minimum inhibitory concentration of ofloxacin $0.1 \mu \mathrm{g} / \mathrm{ml}$ against E. coli (Zeng et al., 1996). The serum concentration-time curve showed that the drug obeyed a twocompartment open model. Hartmut et al. (1987) in human and Liu and $\overline{\text { Kafr El-Sheikh Vet. Med. J. Vol. } 3 \text { No. } 1 \text { (2005) }}$ 
Fung (1997) in chickens described the serum ofloxacin concentrationtime curve after intravenous administration by a two-compartment open model. Himangshu et al. (2004) described the serum ofloxacin concentration-time relationship after intravenous injection of $5 \mathrm{mg} / \mathrm{kg}$ b.wt. in goats by non- compartmental model. This variation might be attributed to species differences as well as to the sensitivity of each method of assay.

ofloxacin was rapidly distributed extravascularly in normal and diseased chickens Following intravenous administration of $5 \mathrm{mg}$ ofloxacin $/ \mathrm{kg}$ b.wt as indicated by the mean values of distribution half-lives $\left[\mathrm{t}_{0.5(\alpha)}\right]$ and transfer rate constant $\left(\mathrm{K}_{12}\right.$ and $\left.\mathrm{K}_{21}\right)$ as well as $\mathrm{K}_{12} / \mathrm{K}_{21}$ ratio $(>1)$.

The mean apparent volume of distribution obtained by the steadystate $\left(\mathrm{Vd}_{(\mathrm{ss})}\right)$ method were $2.07 \pm 0.20$ for normal chickens and $2.47 \pm$ 0.21 for infected chickens. This indicates that ofloxacin was distributed in tissues more than blood which might be attributed to its less extensive binding to plasma protein (15.98\%). This was an expected finding for tissue penetrating the fluroquiolones such as ofloxacin. Our findings is in agreement with the values obtained by Hartmut et al. (1987), Liu and Fung (1997) and Himangsh et al. (2004) in human, chickens and goats, respectively.

The mean elimination half-lives $\left(\mathrm{t}_{0.5(\beta)}\right) 8.66 \pm 0.51 \mathrm{~h}$ in normal chickens and $6.93 \pm 0.41 \mathrm{~h}$ in diseased one indicate that the chickens eliminate ofloxacin slowly. A relatively shorter half-life has been reported in man (5.4 h) by Farinotti et al. (1998), rabbit (1.5-1.9 h) by Marangos et al.(1997)and in chicken (4.82 h) by Liu and Fung (1997). Meanwhile, Himangshu et al. (2004) reported longer elimination half-life in goats $(15.58 \mathrm{~h})$. This variation in elimination half-life may be attributed partially to species variance as well as to the sensitivity of methods of assay. Ofloxacin body clearance $\left(\mathrm{Cl}_{\mathrm{B}}\right)$ was $0.36 \pm 0.02$ in normal chickens and $0.44 \pm 0.03 \mathrm{~L} / \mathrm{h} / \mathrm{kg}$ in diseased one indicate high clearance rate which reflected on the mean residence time (MRT) of the drug in the body. 
Following single oral administration of $5 \mathrm{mg}$ ofloxacin/kg b.wt. in normal and diseased chickens, the drug could be detected over 24 hours with a mean value of $0.13 \mu \mathrm{g} / \mathrm{ml}$ and $0.087 \mu \mathrm{g} / \mathrm{ml}$ for normal and diseased chickens, respectively. These values are within the range of MIC of ofloxacin $(0.1 \mu \mathrm{g} / \mathrm{ml})$ against $E$. coli strain(Zeng et al.,1996). The disposition kinetics following a single oral administration of $5 \mathrm{mg}$ ofloxacin $/ \mathrm{kg}$ b.wt. in normal and diseased chickens revealed that ofloxacin is absorbed rapidly in diseased chickens $\left(2.51 \pm 0.11 \mathrm{~h}^{-1}\right)$ than in normal one $(1.90 \pm$ $\left.0.10 \mathrm{~h}^{-1}\right)$.

The absorption half-lives $\left(\mathrm{t}_{0.5(\mathrm{ab})}\right)$ and calculated maximum serum concentration $\left(\mathrm{C}_{\max }\right)$ were $0.36 \pm 0.03 \mathrm{~h}$ and $1.14 \pm 0.11 \mu \mathrm{g} / \mathrm{ml}$ for normal chickens and $0.28 \pm 0.02 \mathrm{~h}$ and $0.99 \pm 0.07 \mu \mathrm{g} / \mathrm{ml}$ for diseased chickens, respectively.Hartmut et al. (1987) reported the $\mathrm{t}_{0.5(\mathrm{ab})}$ and $\mathrm{C}_{\mathrm{max}}$ in normal volunteers were $36.1 \pm 20.5 \mathrm{~min}$ and $2.19 \pm 0.43 \mu \mathrm{g} / \mathrm{ml}$ which was attained at $\mathrm{t}_{\max }$ equal to $76.8 \pm 39.2 \mathrm{~min}$. this variation might be attributed to the anatomical and physiological variation between man and chickens as well as the health status of each species.

The apparent elimination half-life following oral administration of $5 \mathrm{mg}$ of ofloxacin $/ \mathrm{kg}$ b.wt. in normal and diseased chickens were $7.00 \pm$ 0.55 hours and $6.44 \pm 0.43$ hours, respectively, which were within the range reported in man (334 $\mathrm{min}$ ) (Hartmut et al., 1987). Calculation of the AUC after $5 \mathrm{mg}$ ofloxacin/ $\mathrm{kg}$ b.wt.intravenous and oral administration in normal chickens showed nearly the same results, thus indicating an excellent absolute bioavailability $(91.9 \pm 8.25 \%)$ of ofloxacin following oral administration.Similar results were obtained byHartmut et al.(1987) in human but Liu and Fung (1997) reported bioavailability of $129.4 \%$ after oral administration in chicken. This difference may be attributed to dose difference and method of assay. 
Results of the in vitro serum protein binding showed low protein binding $(15.89 \%)$ suggesting that conditions which alter protein binding would not influence the drug pharmacokinetics. Ofloxacin has been reported to be about 15.28 bound to serum in goats (Himangshu et al., 2004).

In conclusion, because of the bactericidal advantage and pharmacokinetic properties reported, clinical application of ofloxacin in veterinary medicine can be of considerable advantage.

\section{REFERENCES}

- Arret, B.; Jahnson, D.P. and Kirshbaum, A. (1971): "Out line of details for microbological assays of antibiotics." J. Pharm. Sci., 60: 1690- 1694.

- Baggot, J.D. (1977): "Principle of drug disposition in domestic animals." Philadelphia, W.B. Saunders company.

- Baggot, J.D. (1978): "Some aspect of clinical pharmacokinetic, in veterinary medicine II.." J. Vet. Pharm. Therap. 1: 111- 118.

- Barnes, H.J. and Gross, W.B. (1997): "Colibacillosis. In; diseases of poultry." 10th edition B.W Calnek et al., Iowa state University press, Ames Iowa Pp. 131- 141.

- Barun, M.; Ghose, R.K. and Maulik, B. (2000): "Disposition kinetic of ofloxacin in black Bengal goats following single oral administration." Indin. J. Animal Health. 39: 2, 56- 60.

- Berly, D.A. and Lindgrem, B.W.(1990): "Statistics: Theory and Methods." Brooks/ Cole Publishing Company, Pacific Grove California. 
- Cheville, N.F. and Arp, L.H. (1978): "Comparative pathologic findings of Escherichia coli infection in birds." J. Am. Vet. Med. Assoc. 173: 584- 587.

- Farinotti, R.; Trouvin, J.H.; Bocquet, V.; Vermeric, N. and Carbon, C. (1998):"Pharmacokinetics of ofloxacin after single and multiple intravenous infusion in healthy subject."Antimicrob. Agents Chemother.,32: 1590-1592.

- Gibaldi, M. and Perrier, D. (1982): "Non compartmental analysis based on statistical moment theory." In pharmacokinstics 2nd ed. Pp. 409- 417. Marcel Dekkr, New York.

- Hartmant, L.; Gert, H.;; Peter, O.; Brend, S.; Andreas, K.; Klaus, B. and Peter, K. (1987): " Pharmacokinetics of ofloxacin after parenteral and oral administration." Antimicrob. Agent Chemother., 31 (9): 1338-1342.

- Himangshu, B.; Dulal, C.R.; Rohini, K.R. and Hirendra N.K. (2004): "Pharmacokinetics, tissue residue and plasma protein binding of ofloxacin in goats." J. Vet. Sci., 5 (2): 97-101.

- Kemmerich, B.; Small, G.J. and Pennington, J.E. (1986): "Comparative evaluation of ciprofloxacin, enoxacin and ofloxacin in experimental Pseudo-monas aeruginosa pneumonia."Antmicrob. Agents and Chemotherapy,29(3): 395- 399.

- Lamp. K.C.; Bailey, E.M. and Rybak, M.J. (1992): "Ofloxacin clinical pharmacokinetic ." Clin. Pharmacokinet. 22 (1): 32- 46.

- Liu, Y. and Fung, K.F. (1997): "Pharmacokinetic studies of ofloxacin in healthy and diseased chicken infected with Mycoplasma gallinarum and E. coli." J. Vet. Pharmacol. Therp. 20: 181- 218.

- Lorian, V. (1975): "Antibiotic in laboratory medicine." USA, 265297. 
- Marangos,M.N.;Zhu,Z.;Nicolus,D.P.;Klepser, M.T. and Ightingle, C.H. (1997): "Disposition of ofloxacin in female New Zealand white rabbits." J. Vet. Pharmacol. Ther., 20: 17-20.

- Monk, J.P. and Campoli- Richards, D.M. (1987): "Ofloxacin a review of its antibacterial activity, pharmacokinetic properties and therapeutic use." Drugs. 33 (4): 346- 91.

- Pages, A. and Costa, L. (1985): "Factors potentiating the pathogenicity of E. coli in broilers." Medicina Vet., 2: 23- 40.

- Perkins,R.J.;Liu,W.;Drusano,G.; Modu, A.; Mayers, M.; Madu, C. and Miller, M.M. (1995): "Pharmacokinetics of ofloxacin in serum and vitreous humor of albino and pigmented rabbits." AntimirobAgents Chemother. 39 (7): 1493- 8.

- Son, D.S.; Ikenoue, N.; Tagawa, Y.; Shimoda, M. and Kokue, E. (2000): "Non liner pharmacokinetics of ofloxacin after a single intravenous bolus in pig." J. Vet. Pharmacol. Therap. 23: 5, 311315.

- Wellington, P.G. and Craig, W.A. (1976): "Pharmacokinetics in disease states modifying renal function."In:The effect of disease states on drug phar-macokinetics." Benet, L.Z. (Ed.), pp. 155-187, American Pharmaceutical Association, Washington.

- Wolfson, J.S. and Hooper, D.C. (1989): "Comparative pharmacokinetic of ofloxacin and ciprofloxacin." Am. J. Med. 29, 87 (6C): 318- 365 .

- Yabe,K.;Murakami,Y.;Nishida,S.;Sekiguchi,M.; Furuhama, K.; Goryo, M. and Okada, K. (2001): "A non- arthropathic dose and its disposition following oral administration of ofloxacin, a new quinolone antimicrobial agent, to juvenile dogs." J. Vet. Med. Sci. 63: 8, 867- 872 . 
- Zeng-Zhenling,Liu-Yahong,Sun-Yong xue,Huang-XianHui, Zeng, Z.L.; Liu,Y.H.;Sun,Y.X.and Huang,X.H. (1996): "Efficacy of ofloxacin against experimental colibacillosis in chickens."Chinese $\mathrm{J}$. Vet.Sci., 16 (5): 470-473. 